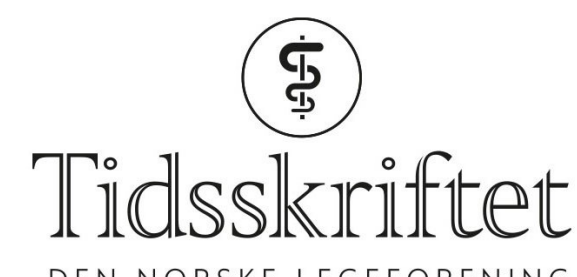

DEN NORSKE LEGEFORENING

\title{
Trikobesoar
}

KORT KASUISTIKK

\section{SUSANNE OHNESORGE}

Avdeling for gastro- og barnekirurgi

Oslo universitetssykehus

Susanne Ohnesorge er lege i spesialisering i barnekirurgi.

Forfatteren har fylt ut ICMJE-skjemaet og oppgir ingen interessekonflikter.

\section{HANS SKARI}

Avdeling for gastro- og barnekirurgi

Oslo universitetssykehus

Hans Skari er ph.d., spesialist i generell kirurgi og i barnekirurgi og overlege.

Forfatteren har fylt ut ICMJE-skjemaet og oppgir ingen interessekonflikter.

\section{KRYSTIAN ZOCHOWSKI}

Avdeling for radiologi og nukleærmedisin

Oslo universitetssykehus

Krystian Zochowski er spesialist i radiologi og overlege.

Forfatteren har fylt ut ICMJE-skjemaet og oppgir ingen interessekonflikter.

\section{EVA MARIA PEKRUN}

Avdeling for radiologi og nukleærmedisin

Oslo universitetssykehus

Eva Maria Pekrun er spesialist i radiologi og overlege.

Forfatteren har fylt ut ICMJE-skjemaet og oppgir ingen interessekonflikter.

\section{OLE SCHISTAD}

Avdeling for gastro- og barnekirurgi

Oslo universitetssykehus

Ole Schistad er spesialist i generell kirurgi og i barnekirurgi og overlege.

Forfatteren har fylt ut ICMJE-skjemaet og oppgir ingen interessekonflikter.

\section{PÅL AKSEL N\&SS}

E-post: paanae@ous-hf.no

Avdeling for traumatologi

Oslo universitetssykehus

og

Institutt for klinisk medisin

Universitetet i Oslo

Pål Aksel Næss er spesialist i generell kirurgi og i barnekirurgi, overlege og professor.

Forfatteren har fylt ut ICMJE-skjemaet og oppgir ingen interessekonflikter.

Et barn i tidlig skolealder ble innlagt med noen dagers sykehistorie med magesmerter, oppkast og en palpabel oppfylling i øvre del av abdomen. Utredningen viste at det dreide 
seg om en svært uvanlig årsak til magesmertene.

Barnet hadde hatt oppkast og magesmerter i fire dager. Henvisende lege hadde palpert en stor oppfylling i øvre del av abdomen. Siste avføring var minst to dager tilbake i tid. Barnet var under barnepsykiatrisk oppfølging for trikotillomani (napping av hår) og trikotillofagi (svelging av hår).

Ved undersøkelse var pasientens allmenntilstand god, men det var en hard oppfylling på ca. $20 \mathrm{~cm}$ i diameter fra epigastriet ned til under navlenivå. Blodprøvene viste hemoglobin 10,5 g/dl (referanseområde 11,0-15,5) og alaninaminotransferase (ALAT) 49 U/L (10-45). $\emptyset$ vrige lever- og galleprøver samt CRP- og leukocyttverdier var normale.

Ultralydundersøkelse av abdomen påviste en oppfylling på magesekkens plass. Denne var også synlig på røntgen oversikt abdomen. Supplerende røntgenkontrastundersøkelse fremstilte en oppfylling som inntok hele magesekken, forenlig med en "svært stor besoar» (figur 1). På bakgrunn av opplysningene om tidligere trikotillofagi antok man at det dreide seg om en trikobesoar.

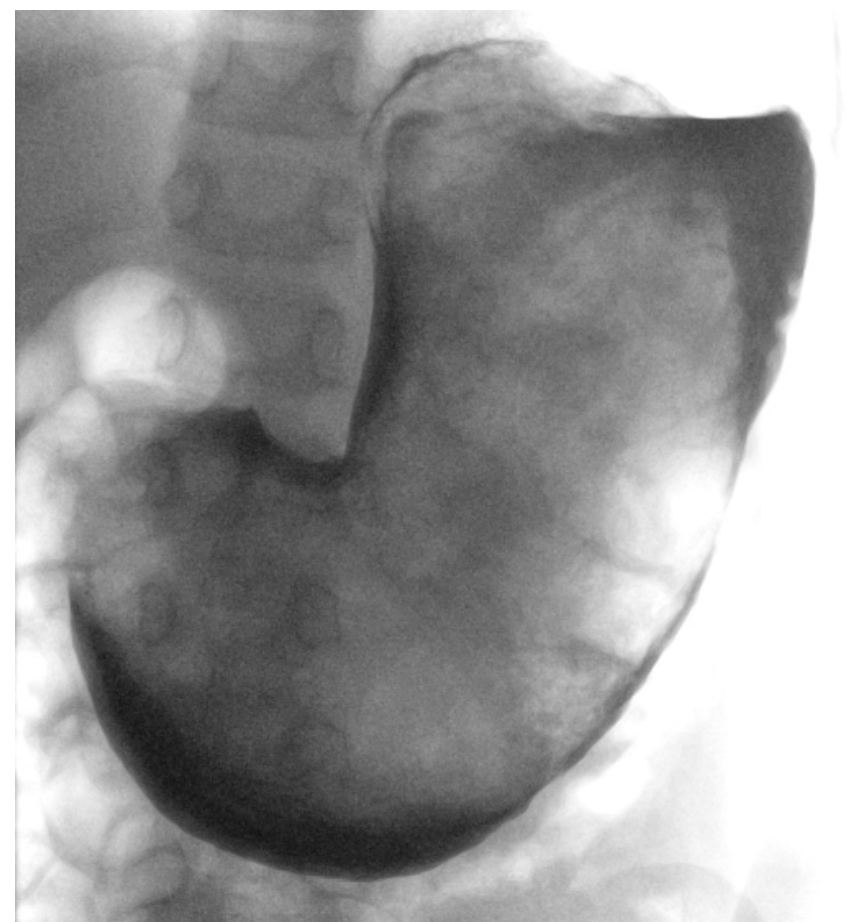

Figur 1 Røntgenbildet viser en ikke-veggfast oppfylling (omgitt av kontrast) i magesekken.

Dette ble bekreftet ved laparotomi samme dag. Man fjernet en trikobesoar som fylte hele magesekken, med en ca. $60 \mathrm{~cm}$ lang utløper som ble trukket retrograd opp fra tynntarmen (figur 2). Trikobesoaren veide over $750 \mathrm{~g}$. Det postoperative forløpet var ukomplisert, og pasienten ble utskrevet femte postoperative dag med avtale om videre barnepsykiatrisk oppfølging. 


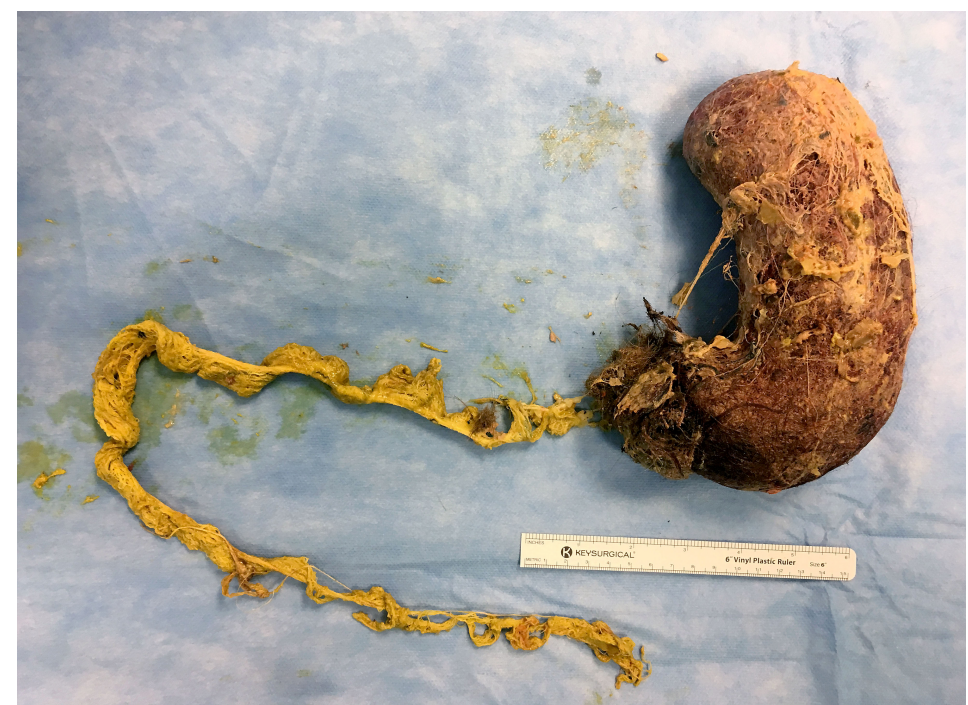

Figur 2 Trikobesoaren formet som magesekken, med en om lag $60 \mathrm{~cm}$ lang utløper.

\section{Diskusjon}

Besoar er en opphopning av ufordøyelig materiale i gastrointestinalkanalen, vanligvis lokalisert i magesekken (1-4). Dersom den består av hår, betegnes den som trikobesoar $(1,2)$. For at en trikobesoar skal dannes, må pasienten i en lengre periode nappe hår i betydelig grad (trikotillomani) og deretter svelge det (trikotillofagi). Dersom magesekkperistaltikken ikke medfører at håret føres over i tynntarmen, vil det gradvis danne seg en større ansamling av hår i magesekken. Det er anslått at om lag 1 \% av personer med alvorlig trikotillomani vil få en besoardannelse som krever kirurgisk intervensjon $(1,5)$.

I en klinisk oversiktsartikkel om trikotillomani i Tidsskriftet i 2018 beskrives dette som en psykisk lidelse som typisk rammer i ungdomsårene og har et kronisk forløp. Sammenlignet med atferdsterapi har medikamenter beskjeden effekt på denne lidelsen. De fleste pasientene responderer på atferdsterapi, hvor over halvparten oppnår remisjon (6). I artikkelen anslår man en livstidsprevalens på o,6-2,4 \% og at 5-18 \% av hårnapperne svelger hår (6).

Trikobesoarer kan nå betydelig størrelse før de gir symptomer som beskrevet i denne kasuistikken der hele magesekken var utfylt av besoaren (figur 1). Videre preoperative undersøkelser var ikke nødvendig. CT-undersøkelse med kontrast er rapportert å kunne diagnostisere $97 \%$ av besoarer i magesekken (7), men representerer en betydelig strålebelastning, som det var mulig å unngå hos dette barnet.

Som det framgår av figur 2, var hoveddelen av besoaren over $20 \mathrm{~cm}$ lang og største diameter om lag $10 \mathrm{~cm}$. Den beholdt form som magesekken etter fjerning. Dette skyltes at den var svært kompakt, og den ville ikke ha egnet seg for endoskopisk fjerning, som ofte viser seg å ikke være vellykket (2). Laparotomi med gastrotomi anbefales ved fjerning av store trikobesoarer i magesekken (2).

Trikobesoaren hadde en $60 \mathrm{~cm}$ lang hale (figur 2). Den var palpabel et godt stykke ned i jejunum og lot seg fjerne ved forsiktig traksjon gjennom åpningen i magesekken. Dersom dette ikke hadde latt seg gjøre, måtte man ha fjernet utløperen gjennom en separat åpning av tynntarmen for å hindre at den kilte seg fast og forårsaket tarmobstruksjon (2). En slik hale forekommer i et fåtall av tilfellene $(4,8)$, men har på grunn av det karakteristiske utseendet blitt kjent under et eget navn i medisinsk litteratur, Rapunsels syndrom $(2,4,6)$. Navnet henspiller på den lange hårmanken til Rapunsel som var fanget i tårnet, kjent fra brødrene Grimms eventyrsamling fra 1812.

Selv om trikobesoar er en sjelden tilstand, må man vurdere den hos pasienter med trikotillofagi og abdominalsymptomer. Symptomgivende trikobesoarer er ofte av en slik størrelse at de er palpable ved enkel klinisk undersøkelse, som i den presenterte kasuistikken. Et slikt funn må føre til videre diagnostikk i sykehus. 
1. Bouwer C, Stein DJ. Trichobezoars in trichotillomania: case report and literature overview. Psychosom Med 1998; 6o: 658-6o. [PubMed][CrossRef]

2. Castle SL, Zmora O, Papillon S et al. Management of complicated gastric bezoars in children. Isr Med Assoc J 2015; 17: 541-4. [PubMed]

3. Sharma V, Gupta H, Lamoria S et al. Tale of a hairy tail: Rapunzel Syndrome. Intern Emerg Med 2016; 11: 759-6o. [PubMed][CrossRef]

4. Lalith S, Gopalakrishnan KL, Ilangovan G et al. Rapunzel Syndrome. J Clin Diagn Res 2017; 11: TDo1-02. [PubMed]

5. Frey AS, McKee M, King RA et al. Hair apparent: Rapunzel syndrome. Am J Psychiatry 2005; 162: 242-8. [PubMed][CrossRef]

6. Eskeland SO, Moen E, Hummelen B. Trikotillomani. Tidsskr Nor Legeforen 2018; 138. doi: 10.4045/tidsskr.17.0599. [PubMed][CrossRef]

7. Ripollés T, García-Aguayo J, Martínez MJ et al. Gastrointestinal bezoars: sonographic and CT characteristics. AJR Am J Roentgenol 2001; 177: 65-9. [PubMed][CrossRef]

8. Naik S, Gupta V, Naik S et al. Rapunzel syndrome reviewed and redefined. Dig Surg 2007; 24: 157-61. [PubMed][CrossRef]

Publisert: 23. november 2020. Tidsskr Nor Legeforen. DOI: 10.4045/tidsskr.20.0472

Mottatt 22.5.2020, første revisjon innsendt 9.9.2020, godkjent 18.9.2020.

(C) Tidsskrift for Den norske legeforening 2020. Lastet ned fra tidsskriftet.no 